Research Article

\title{
Estimating the Impacts of Corporate Governance of the Financial Performance on Non-Financial Firms of Bangladesh
}

\author{
Ishtiaq Ahmad ${ }^{1 *}$, Abid Usman ${ }^{1}$, Khursheed Iqbal ${ }^{1}$ and Shams Ur Rehman ${ }^{2}$
}

${ }^{1}$ Department of Management Sciences, Iqra National University, Peshawar, KPK, Pakistan; ${ }^{2}$ Department of Management Sciences, Institute of Business and Management Sciences, Agricultural University, Peshawar, KPK, Pakistan.

\begin{abstract}
Corporate governance study is growing rapidly as compliance with corporate governance is mandatory. Multiple questions rose regarding measurement of Corporate Governance Practices. In this study, the authors argue whether the Corporate Governance characteristics influence the firm performance of NonFinancial Firms in Bangladesh. In this study, three types of industries like pharmaceutical, cement, and food were analyzed from the Dhaka Stock Exchange, Bangladesh for the period of 2010 to 2019. The authors used the diagnostic test on data that argued that the model is better, like the fixed effect model or random-effect model for analysis. Multiple regression based methodology was developed to use fixed-effect model for both dependent variables Return on Assets and Tobin- $Q$ variables to discover the association between Corporate Governance and Firm Performance. It is concluded that Board Size, Board Gender, Board Experience and firm size have significant the ROA and Chief Executive Duality, Board Size, Board Gender, Board Experience, and Firm size have significant with Tobin-Q.

Received: January 20, 2021; Accepted: May 01, 2021; Published: June 30, 2021

*Correspondence: Ishtiaq Ahmad, Department of Management Sciences, Iqra National University, Peshawar, Khyber Pakhtunkhwa, Pakistan; Email: ishtiaq.6618.phd@inu.edu.pk

Citation: Ahmad, I., A. Usman, K. Iqbal and S.U. Rehman. 2021. Estimating the impacts of corporate governance of the financial performance on non-financial firms of Bangladesh. Journal of Engineering and Applied Sciences, 40(1): 78-90.

DOI: https://dx.doi.org/10.17582/journal.jeas/40.1.78.90

Keywords: Corporate governance, Firm performance, Board size, Board gender, Board experience, Firm size, ROA, Tobin-Q
\end{abstract}

\section{Introduction}

Tn Bangladesh, the question of corporate IGovernance in business sector becomes more relevant keeping in view the dominance of business organizations as a sine a quinine of economic progress. Corporate Governance may be construed as a system of managing large enterprises with the tools of planning, organizing, directing, coordinating, and controlling with a view to achieve both individual and corporate goals. As per provisions of the companies Act 1994 (which is practiced in Bangladesh), 'Board of Directors' is responsible for the good governance of their companies. Thus, good governance is a system to ensure that the company is managed is the best interests of all stakeholders and other various interest groups.

To study Bangladesh in growing economy is a good topic for study. There are two side of the study of Corporate Governance on is the wealthy economic situation and second side increases queries regarding the sustainability. It will be mentioned that from last 30 thirty years, the gross national product of Bangladesh is notable expedition. The Gross Domestic Product (GDP) progress of Bangladesh is exception is 5.69 from 1994 to 2016 and going to improving to 7.10 in 2019. The Bangladesh government keep a target till 2021 for the achieving the Middle Income Country (MIC) position in the world economic by 
make sure to maintained his Gross Domestic Product annual $8 \%$. However, on the other side the country economic position is not good for the obtaining of GPD to annually 8\%. According to (Sobhan and Bose, 2019; Hasan and Song, 2013; Francis et al., 2012) that contempt this healthy improvement rate of the Bangladesh, the country is still in poorest position overall the world. If the Bangladesh want to achievement of position in MIC in world economic market its need to manage and maintain all the sector which performing a good role for the improvement of the growth GDP. However, on the contrary, the country is facing multiple corporate flattery growing year by year. A few examples of its corporate flattery is Modern Food Ltd, Hallmark Bismillah Groug and Oriental Bank. In corporate flattery, the failure of two stock market performance also very highlighted in 1996 and 2011.

The conflicting summary is not unusual in Bangladesh, preferably most of the countries are working in same position, which certain countries working on managing best governance position and developing their codes. In these regards, multiple studies have been conducted to emphasizing on the important of improvement and judgment the level of resists. According to Reeze at al. (2002), they proved through experiment that the exposure of resists have positive affect on the stock market. In addition, according to Abbas at al. (2013); Bohren and Strom (2010); Rehman and Khatun (2017) it is depicted that if the performance has improved it will also have positive affect on the stock market. The results of study non-affect increase to admit the countries to find out the difference between the conventional and originally which performance relevant action for the improvement of code (Muttakin et al., 2012). According to (Costa, 2015), the report of corporate governance working is the best practices amount the developing countries, since the corporate governance is helps to best change in governance standard which good result to financing, the cost of capital will low, good performance and pleasant help of all shareholder and stock holders and necessary for the Bangladesh to implement the good governance practices. According to Claessens and Yurtoglu (2013), study depicts that the practices of Corporate Governance are performed the key role in the economy especially in the developing countries because its relief the enhance the corporate governance characteristics, which in revolve advantage companies concluded highly entrée to financing, the capital cost going to lower side, great outcome and convenient care of all stockholders and shareholders and it is because it is the essential for Bangladesh to guarantee its better governance characteristics if Bangladesh want achieve it blooming objectives. A survey by Whiting et al., (2015) examined form 2007 and 2011 and argued that the chief executive officer has a great connection with maximum level of tax escape. The result of study by Armstrong et al. (2013) depicts that the connection between risk-taking equity benefit and remuneration of shareholder is positive. The non-financial companies sectors face little appearance because of governance prevailing.

Following the strength, Bangladesh has also established its first contributed code of corporate Governance in the year of 2004 and the Bangladesh Security and Exchange Commission $1^{\text {st }}$ time introduced the Corporate Governance Regulation for its companies in 2006 with the condition of fulfill or define and these regulations also amended in 2012 for implementation on all the listed companies. Even so, it is already argued that the Code have been earning better because of the improvement in governance prevailing. Even though some of the studies i.e., (Sobhan, 2016; Ahmed and Yusuf, 2005; Belal, 1999, 2001, 2002; Belal and Owen, 2007; Imam and Malik, 2007; Siddiqui, 2010; Sobhani et al., 2009; Uddin and Choudhury, 2008; Uddin and Hopper, 2003) argued that review comprehension the governance in Bangladesh some types of new compulsory and managerial necessities, no part has measured awareness the degree to have companies in Bangladesh review the level of International Standard of Governance thoroughly assessments acquiescence against which are depicted by the Bangladesh Code of Corporate Governance for the year 2004.

According to Habib (2016), when chief executive have dual charge i.e., CEO and chairman of Board have an increase in the firm profitability on increase of Return on Asset (ROA). According to Masud et al. (2017), the banking sector of listed companies of Bangladesh between 2010 and 2015 and depicts the results beneficial because the corporate Governance influence on ROA, which means that in the implementation of Corporate Governance practices in banking sector listed companies its profitability has increase.

Moreover, good corporate governance serves two 
essential functions, i.e., to boost firm performance by establishing and maintaining a corporate environment; and to encourage the employees of a firm to enhance the corporate operational efficiency. Therefore, it is essential for executives and directors to work efficiently both for interest in a company as well as for the shareholders. In addition, it could be achieved through implementing best practices of corporate governance. Shareholders thought that firm with good governance will return more free cash flow as a dividend (Shleifeer and Wolfeenzon, 2002). A Good Corporate Governance (GCG) reduces the capital cost due to monitoring and auditing costs (Drobetz et al., 2004). Good corporate governance, improve competitiveness by improving competition in product markets, labor productivity, level of investment; and creating a more stable environment in the firm.

\section{Literature review}

Substantiation from prior experiential studies from literature has needed to verify the fulfilment of corporate governance on a firm's performance.

The code of Corporate Governance has highly increasing from the last few years in the Developing and developed countries as studied by the authors i.e. (Alabdullah et al.,2014; Myring and Shortridge, 2010; Mutawaa and Hewaidy, 2010; Silveira and Saito, 2009; Hossain, 2008; Garay and González, 2008; Parsa et al., 2007; Klapper and Love, 2004; Gompers et al., 2003; Conyon and Peck, 1998). Although, the studies examined acquiescence are preponderantly placed on the developed countries code. Appealingly, most authors argued the encouraging (i.e., Akkermans et al., 2007; Pass, 2006; Werder et al., 2005; Dahya et al., 2002). All the attributes is discussed in aspect as under:

\section{Duality of the CEO}

While the contribution of duality to the business does not exist, empirical studies indicate that the Chairman or CEO of the Board will be different from the CEO between shareholders, institutional investors and decision-makers (Rouf, 2011). Dahya et al. (2009) in their report (2009) stated that between 1994 and 2003 in 15 industrialized nations the Chairman or Chairman would not be the same as the Chief Executive Officer and that the UK. The role of chairman and managing directors of an undertaking has been separated in Europe by $84 \%$ of the undertakings (Heidrick and Struggles, 2009). According to Hewa-Wellalage and Locke (2011), Sri Lanka points to the balance of power in the company to reduce the impact of any person on the decisionmaking process. Such rules suggested that in order to guarantee a stable, fair and efficient functioning of the board, a number of independent Board members would be majority in a corporate duality. This analysis thus establishes the research hypothesis:

$\mathrm{H}_{1}$ : Is there is any significant effect of CEO Duality on company efficiency?

\section{Board's size}

The relationship between a board's size and a company's success is two separate ways of thought. The first think tank to make the organization more successful (Lipton and Lorsch, 1992; Jensen, 1993; Yermack, 1996) is championed by a smaller group. The second thinking college, though, believes that the large body will increase its efficiency (Pfeffer, 1972; Klein, 1998; Rouf, 2011; Coles et al., 2008). Such results show that a large board supports and guides businesses more effectively because of the competitive business environment and corporate culture (Klein, 1998). Therefore, there is even more information on a wide wall. A broad board therefore tends to be ideal for firm results (Dalton and Ctg, 1999). From the basis of this analysis, the following is a research hypothesis: $\mathrm{H}_{2}$ : Is there is any significant effect of Board Size on company efficiency?

\section{Board's committees}

The Sub-Committee oversees the company's reporting activities. From the Bottom the Organization Theory Viewpoint, Fama and Jensen (1983) propose the audit, Sub-committees of selection and remuneration carry out different roles in the decision-making process and in the control mechanism of a company. Then it is possible to track firms' operating activities more intensively. This in effect can promote voluntary disclosure and decrease asymmetries in information (Collier, 1993; Fama, 1980; Vafeas, 2000). Carson (2002) outlines the role of the audit, appointment and remuneration committees. The audit committee plays a crucial role in controlling companies in compliance with the regulations. The selection committee considers the expertise of the directors, and periodically reviews the board's results. The compensation committee reports on the terms and conditions of remuneration given to a firm's senior management. An organization can consider using subcommittees to ensure that 
monitoring activities are carried out effectively, in order to implement better control and openness, and to reduce asymmetry of information.

$\mathrm{H}_{3}$ : Is there is any significant effect of Board Committees on company efficiency?

\section{Board's education}

The role of the Board is to operate a business internally (Fama, 1980). A committee is also a mechanism for customer management (Fama and Jensen, 1983). The effectiveness of the company should be increased by a board of directors that effectively manages management decisions. It makes it possible for any Member of the Management Board to have management expertise such as finance, accounting, marketing, IT, legal issues and other related policy areas. This allows each board member to contribute substantially to the decisions taken by management, which are then transformed into the results of the company (Nicholson and Kiel, 2004; Ferreira et al., 2007). On the basis of the above analysis, a research hypothesis is formed as follows: $\mathrm{H}_{4}$ : Is there is any significant effect of Board Education on company efficiency?

\section{Board's gender}

Since blacks and women turned out to be a greater proportion of the work force in the new world, firms are seeing substantial improvements in categories of potential senior executive candidates (Berke and Nelson, 2002). In recent years, issues of class and minority in corporate governance have created controversy. Dobbin and Jung (2011) concluded that diverse teams strive to be more effective and faster in addressing workplace challenges. In fact, the internal decision-making processes were taken by teams with demographic and functional perspectives, thereby improving the consistency of the organizational decisions. I argue further that diversity stimulates imagination and innovation. The authors concluded that diversity brings synergistic advantages for an organization. The writers related back to the principle of social diversity.

$\mathrm{H}_{5}$ : Is there is any significant effect of board gender on company efficiency?

\section{Board's experience}

The board members' perspectives play a crucial role in enhancing the organization's efficiency. The board members' experience and know-how contribute significantly to the firm's performance. According to restrained theory board resources associates with more experience and know-how perform better and effectively handle organizational problems. Hence, the organization's human resource officer seeks to pick most qualified applicants during the process of screening.

$\mathrm{H}_{6}$ : Is there is any significant effect of Board Experience on company efficiency?

\section{Board's nationality}

Janis developed the idea of group-think in 1972 which was extensively debated in the 70 s and 80 s. The definition was created to describe mechanisms of decision-making that can lead to mistakes, accidents and terrorism types. Strategic blunders such as the Nazi decision to attack the Soviet Union in 1941 and Ford's ill-fated introduction of the Edsel in 1958 are manifestations of collective reasoning triggered by an inadequate examination of options and goals, inability to analyze the hazards of choice and lack of knowledge, interpreted in a skewed manner (Sunstein, 2009). The community thought mentality makes individuals with views beyond the comfort zone stop sharing their thoughts and opinions in the consensus of a committed party. Members belonging to a certain group, in this context, try to minimize conflict and reach consensus, to the detriment of other objectives. The group-thinking manifestations include a stereotyped perception of rivals or competitors, constant rationalization and uniformity stresses, in addition to self-censorship related to the idea of unanimity. The factors are related to the community leaders' unity, alienation, lack of a leader who fosters discussion and social and cultural homogeneity (Sunstein, 2009).

$\mathrm{H}_{7}$ : Is there is any significant effect of Board Nationality on company efficiency?

\section{Firm size}

Size is found at every firm as a significant output determinant. Multiplying in scale has always been the company's goals to get an advantage on their rivals. Scale economies the technically explain the positive relationship between scale and efficiency. However, other companies had low results on an annual basis while growing in number. The reviewed literatures established the reason behind the negative relation between size and performance; Kouseret al. (2012) traced the issue to the achievement of company managers' personal interest. Maja and Josipa (2012) have emphasized the question of combining the organizational income maximization motive with managerial utility maximization. Baumol (1959) 
accepted that larger companies could contribute to an increase in the need for teamwork, making management activities challenging, resulting in inefficiencies and lower revenues.

$\mathrm{H}_{8}$ : Is there is any significant effect of Firm Size on company efficiency?

\section{Board compensation}

There has been discussion of the relationship between board pay and corporate governance from various perspectives. Compensation applies to the advantages that the company's employees receive in return for the job. This involves incentives, holiday pay, income sharing, appreciation bonuses and incentives such as equity shares, company-paid accommodation and company-paid vehicles in some cases. Broadly speaking, board of directors pay arrangements consist of stocks, assets, and stock options. Empirical data suggests that high pay has the power to suit employee priorities. Scholars in the area of corporate governance propose that managers be motivated to act in the best interests of the stockholders through financial and non-financial opportunities.

$\mathrm{H}_{9}$ : Is there is any significant effect of Board Compensation on company efficiency?

\section{Hypothesis summary}

The author in this study has find out the chief executive duality, firm size, board education, board experience, board gender, board committee, board nationality, firm size, and board compensation effect on the firm performance is significant or insignificant in combined three industries like cement, food and pharma for the period of 2010-2019.

\section{Materials and Methods}

In this study, the authors have deployed the qualitative research method because the data are available in numerical form on the websites of non-financial firms of Bangladesh. The data is collected from annual reports of the pharmaceutical, cement and food companies listed on Dhaka stock exchange of Bangladesh through the internet from the company websites.

In this study, the proportionate sampling technique has used because the sampling data has been collected based on availability and size of firms. This study has conducted on three industries, namely, cement industry, food industry and pharmaceutical industry in Bangladesh.Thetargeted non-financialfirms'population includes 53 firms in Bangladesh from 3 sectors. The sample size is selected through (Yamane, 1967).

Table 1: The sample size from each industry is calculated are given below.

\begin{tabular}{llll}
\hline Country & Cement & Food & Pharmaceutical \\
\hline Bangladesh & $7^{*} 28 / 53=4$ & $17^{*} 28 / 53=9$ & $29^{*} 28 / 53=15$ \\
\hline
\end{tabular}

The dependent variables i.e., Return on and Assets (ROA) and Tobin's $\mathrm{Q}$ and independent variables i.e., chief executive duality, board size, board committees, board education, board gender, board experience, board nationality, firm size and board compensation has studied in this paper. The following econometrics model will be used:

\section{Proxy and measurement}

The following proxy and measurement will be used in the paper.

Table 2: Proxy and measurement.

\begin{tabular}{llll}
\hline S. No & Definition & Proxy & Measurement \\
\hline $\begin{array}{llll}\text { Dependent variables } \\
1\end{array}$ & Return on asset & ROA & Net income of the firm divided by total assets of the firm \\
2 & Tobin's-Q & TQ & Total value of the firm in market divide by total assets of the firm \\
Independent variables & & \\
1 & CEO duality & CEDU & Coded "1" if the firm chairman also working on the position of CEO and "0" otherwise \\
2 & Board size & BRSIZ & Number of total board members \\
3 & Board committee & BRCMT & Number of total board committees \\
4 & Board education & BREDU & Percentage of supervisors having financial education \\
5 & Board gender & BRGDR & Number of women present on the board \\
6 & Board experience & BREXP & Percentage of supervisors having professional knowledge or work experience \\
7 & Board Nationality & BM & Number of foreign member in Board \\
8 & Firm size & FRMSIZ & The total Assets of the firms \\
9 & Board & BRCMP & Average compensation of all directors on the board; natural logarithm is taken after adding \\
\hline
\end{tabular}

\begin{tabular}{l|l|l|l}
\hline June $2021 \mid$ Volume 40 & Issue 1 & Page 82
\end{tabular} 


\section{Results and Discussion}

\section{Overview}

In this section, the authors will briefly discuss the collected data and use of statistical model for getting results. In statistical analysis, the authors will find out the mean, median, standard deviation, coefficient of variance, correlation and diagnostics test of all dependent and independent variable of the study. The objective of statistical analysis to determine the impact of Corporate Governance practices on the financial performance and financial behavior of nonfinancial firms in Bangladesh.

Table 3 reports the descriptive statistics of all dependent and independent variables included in the study. The mean ROA is 0.505 , with a standard deviation is 5.029 . The difference between mean and standard deviation is too large therefore, we conclude that the ROA is not consistent in Bangladesh Context. The mean of TQ is 2.27954, with a standard deviation is 10.559 . The difference between mean and standard deviation is too large; therefore, we conclude that the TQ is not consistent in the Bangladesh context. The mean CEDU is 0.228 with a standard deviation is 0.420. The difference between mean and standard deviation is normal; therefore, we conclude that the CEDU is consistent in the Bangladesh context. The mean of BRSIZ is 7.235 , with a standard deviation is 1.958 . The difference between mean and standard deviation is too large; therefore, we conclude that the $\mathrm{BRSIZ}$ is not consistent in the Bangladesh context. The mean of BRCMT is 1.635 , with a standard deviation is 0.885 . The difference between mean and standard deviation is normal therefore, we conclude that the $\mathrm{BRCMT}$ is consistent in the Bangladesh context. The mean of BREDU is 2.932, with a standard deviation is 1.280 . The difference between mean and standard deviation is normal therefore; we conclude that the BREDU is consistent in the Bangladesh context. The mean of BRGDR is 0.742 , with a standard deviation is 0.953 . The difference between mean and standard deviation is normal, therefore; we conclude that the BRGDR is consistent in the Bangladesh context. The mean of BREXP is 193.818, with a standard deviation is 80.466 . The difference between mean and standard deviation is too large; therefore, we conclude that the BREXP is consistent in Bangladesh Context. The mean of $\mathrm{BN}$ is 0.146 , with a standard deviation is 0.759 . The difference between mean and standard deviation is normal therefore; we conclude that the
$\mathrm{BN}$ is consistent in the Bangladesh context. The mean of FRMSIZ is 10.240 , with a standard deviation is 1.656. The difference between mean and standard deviation is too large; therefore, we conclude that the FRMSIZ is consistent in the Bangladesh context. The mean of BRCMP is 499.270 , with a standard deviation is 1009.080 . The difference between mean and standard deviation is too large; therefore, we conclude that the BRCMP is not consistent in the Bangladesh context.

Table 3: Descriptive statistics of Bangladesh.

\begin{tabular}{lllll}
\hline Variable & Mean & Median & Std. Dev. & C.V. \\
\hline ROA & 0.505068 & 0.0491659 & 5.02972 & 9.95850 \\
TQ & 2.27954 & 0.339809 & 10.5590 & 4.63208 \\
CEDU & 0.228571 & 0.000000 & 0.420664 & 1.84041 \\
BRSIZ & 7.23571 & 7.00000 & 1.95875 & 0.270706 \\
BRCMT & 1.63571 & 1.00000 & 0.885654 & 0.541448 \\
BREDU & 2.93214 & 3.00000 & 1.28084 & 0.436826 \\
BRGDR & 0.742857 & 0.000000 & 0.953179 & 1.28313 \\
BREXP & 193.818 & 175.500 & 80.4668 & 0.415167 \\
BN & 0.146429 & 0.000000 & 0.759637 & 5.18776 \\
FRMSIZ & 10.2405 & 10.2421 & 1.65614 & 0.161724 \\
BRCMP & 499.270 & 209.001 & 1009.08 & 2.02111 \\
\hline
\end{tabular}

Note: $R O A$ stands for Return on Assets. TQ stand for Tobin's $Q$. CEDU stand for Chief Executive Duality. BRSIZ stand for Board Size. BRCMT stand for Board Committees. BREDU stand for Board Education. BRGDR stand for Board Gender. BREXP stand for Board Experience. BN stand for Board Nationality. FRMSIZ stand for Firm Size and BRCMP stand for Board Compensation.

Table 4 reports the correlation matrix of all dependent variables with independent variables. If we observe the table, we see a negative $(-0.053)$ correlation between ROA and CEDU.It means that the firms' profitability goes downward. A person has the slot of the chief executive officer (CEO) and chairmanship as well, and our result is consistent with the previous result found by Mesut et al. (2013) in turkey. The correlation of ROA and BRSIZ observe in Table 4 we found negative (-0.009). It means that the firms' profitability goes down when the board's size is broad, and our result is consistent with the previous result found by Topak (2011) in turkey. The correlation of ROA and BRCMT observe in Table 4 we found negative $(-0.0614)$. It means that the firms' profitability goes down when a firm has all the committees in working, and our result is consistent with the previous result found by Moreno-Gómez et al. (2017) in Colombo. The correlation of ROA and BREDU observe in Table 4 we found positive (0.0076). It means that the 
firms' profitability goes upward when the committees of the firm have relevant education, and our result is consistent with the previous result found by Darmadi (2011) in Indonesia. The correlation of ROA and BRGDR observe in Table 4 we found negative $(-0.0620)$. It means that the firms' profitability goes upward when the board has female members, and our result is consistent with the previous result found by Khursheed et al. (2016) in Pakistan. The correlation of ROA and BREXP observe in Table 4 we found positive (0.0180). It means that the firms' profitability goes upward when the committees of the firm have relevant experience, and our result is consistent with the previous result found by Darmadi (2011) in Indonesia. The correlation of $\mathrm{ROA}$ and $\mathrm{BN}$ observe in Table 4 we found negative (-0.018). It means that the firms' profitability goes upward when the board has members of multiple nationality. Our result is consistent with the previous result found by Mihaela et al. (2018) in Roman. The correlation of ROA and FRMSIZ observe in Table 4 we found negative $(-0.2959)$. It means that the firms' profitability goes upward when a total asset of the firm count, and our result is consistent with the previous result found by Mihaela et al. (2018) in Roman. The correlation of ROA and BRCMP observe in Table 4 we found negative (-0.0296). It means that the firms' profitability goes upward when the committees of the firm have relevant education, and our result is consistent with the previous result found by Darmadi (2011) in Indonesia.

Table 4 reflects that the correlation between TQ and CEDU is negative $(-0.081)$, which shows that the firm trades in undervalue when a person has the slot of Chief Executive Officer (CEO) and Chairmanship as we and our result is consistent with the previous work found by Mesut et al. (2013) in turkey. The correlation between TQ and BRSIZ is negative (-0.079), which shows that the firm trades in undervalue when the size of the board is large, and our result is consistent with the previous work found by Bøhren and Strøm (2010) in Norway. The correlation between TQ and BRCMT is negative (-0.1095), so it's mean that the firm trades in undervalue when a firm has all the committees in working. Our result is consistent with the previous result found by Madhani (2019) in India. The correlation between TQ and BREDU is negative (-0.0585), so it's mean that the firm trades in undervalue when the committees of the firm have relevant education. Our result is consistent with the previous work found by Darmadi (2011) in Indonesia. The correlation between TQ and BRGDR is negative (-0.0082), so it's mean that the firm trades in undervalue when the board has a female member. Our result is consistent with the previous work found by Darmadi (2011) in Indonesia. The correlation between TQ and BREXP is negative (-0.0048), so it's mean that the firm trades in undervalue when the committees of the firm have relevant experience. Our result is consistent with the previous work found by Joce (2018) in UAE. The correlation between TQ and $\mathrm{BN}$ is negative $(-0.040)$, so it's mean that the firm trades in undervalue when the board has multiple nationality, and our result is consistent with the previous work found by Mihaela et al. (2018) in Roman. The correlation between TQ and FRMSIZ is negative (-0.3479), so it's mean that the firm trades in undervalue when a total asset of the company count, and our result is consistent with the previous work found by Darmadi (2011) in Indonesia. The correlation between TQ and BRCMP is negative (-0.0435), so it's mean that the firm trades in undervalue when the committees of the firm have relevant education. Our result is consistent with the previous result found by Mihaela et al. (2018) in Roman.

Table 4: Correlation matrix of Bangladesh.

\begin{tabular}{|c|c|c|c|c|c|c|c|c|c|c|c|}
\hline & ROA & TQ & CEDU & BRSIZ & BRCMT & BREDU & BRGDR & BREXP & BN & FRMSIZ & BRCMP \\
\hline $\mathrm{ROA}$ & 1 & 0.9681 & -0.053 & -0.009 & -0.0614 & 0.0076 & -0.0620 & 0.0180 & -0.018 & -0.2959 & -0.0296 \\
\hline TQ & & 1.0000 & -0.081 & -0.079 & -0.1095 & -0.0585 & -0.0082 & -0.0048 & -0.040 & -0.3479 & -0.0435 \\
\hline CEDU & & & 1.0000 & 0.0562 & -0.0451 & -0.3503 & -0.0853 & -0.0751 & 0.1304 & -0.3441 & -0.1387 \\
\hline BRSIZ & & & & 1.0000 & 0.4092 & 0.6564 & 0.0326 & 0.7464 & 0.3091 & 0.3415 & 0.2562 \\
\hline BRCMT & & & & & 1.0000 & 0.2751 & -0.2048 & 0.3372 & 0.0902 & 0.3123 & 0.3384 \\
\hline BREDU & & & & & & 1.0000 & -0.1582 & 0.5709 & 0.2386 & 0.5093 & 0.1347 \\
\hline BRGDI & & & & & & & 1.0000 & 0.1466 & -0.052 & 0.0219 & -0.0354 \\
\hline BREXP & & & & & & & & 1.0000 & 0.1369 & 0.4230 & 0.3024 \\
\hline $\mathrm{BN}$ & & & & & & & & & 1.0000 & -0.0328 & 0.0911 \\
\hline FRMSIZ & & & & & & & & & & 1.0000 & 0.3277 \\
\hline BRCMP & & & & & & & & & & & 1.0000 \\
\hline
\end{tabular}

June 2021 | Volume 40 | Issue 1 | Page 84 
Table 5: Dependent variable: $R O A$.

\begin{tabular}{|c|c|c|c|c|c|}
\hline & Coefficient & Std. Error & t-ratio & p-value & \\
\hline Const & 35.684 & 3.0339 & 11.7617 & $<0.00001$ & $* * *$ \\
\hline CEDU & -1.91627 & 1.25741 & -1.5240 & 0.12882 & \\
\hline BRSIZ & -1.69824 & 0.460234 & -3.6899 & 0.00028 & $* * *$ \\
\hline BRCMT & 0.620173 & 0.424764 & 1.4600 & 0.14558 & \\
\hline BREDU & 1.21727 & 0.753905 & 1.6146 & 0.10770 & \\
\hline BRGDR & 0.988454 & 0.495707 & 1.9940 & 0.04727 & $* *$ \\
\hline BREXP & 0.0359921 & 0.0149847 & 2.4019 & 0.01706 & $* *$ \\
\hline $\mathrm{BN}$ & 0.354489 & 0.374058 & 0.9477 & 0.34424 & \\
\hline FRMSIZ & -3.39677 & 0.278449 & -12.1989 & $<0.00001$ & $* * *$ \\
\hline BRCMP & $1.7969 \mathrm{e}-07$ & 0.000658102 & 0.0003 & 0.99978 & \\
\hline R-squared & 0.5234 & & Adjusted $\mathrm{R}^{2}$ & & 0.4525 \\
\hline$F(36,242)$ & 7.3832 & & $\mathrm{P}$-value(F) & & 0.0000 \\
\hline $\mathrm{P}$-value $(\mathrm{CT})$ & 0.0000 & & $\mathrm{P}$-value (BPT) & & 0.0000 \\
\hline P-value (HT) & 0.0000 & & P-value (WT) & & 0.0000 \\
\hline
\end{tabular}

Note: ${ }^{*}, * * * * *$ denotes significance level for $1 \%, 5 \%$ and $10 \%$ respectively.

Model 1: $\mathrm{ROE}=\alpha+\beta 1 \mathrm{CEDU}+\beta 2 \mathrm{BRSIZ}+\beta 3 \mathrm{BREDU}+\beta 4 \mathrm{BREDU}+\beta 5 \mathrm{BRGDR}+\beta 6 \mathrm{BREXP}+\beta 7 \mathrm{BRDIV}+\beta 8 \mathrm{FRMSIZ}+$ $\beta 9 \mathrm{BRINDPit}+\beta 10 \mathrm{BRCMP}+\mathrm{e}$

$R O A$ is dependent variable and stand for Return on Assets. $A$ is constant (intercept). B1 to B10 are regression coefficients. $€$ stands random error. The independent variables are CEDU stand for Chief Executive Duality. BRSIZ stand for Board Size. BREDU stand for Board Committees. BREDU stand for Board Education. BRGDR stand for Board Gender. BREXP stand for Board Experience. BN stand for Board Nationality. FRMSIZ stand for Firm Size and BRCMP stand for Board Compensation. CT, BPT, HT and WT are diagnostic tests and stand foe Chow test, Breusch-Pagan test, Hausman test and Wald test respectively and table of diagnostic tests are presented in appendix A.

\section{Dependent variable return on asset}

Table 5 reports the results of model 3.1 of dependent variable ROA with all independent variables. We have allied fixed effect model as suggested by diagnostic test presented in Appendix A.

We observe the table we found that the coefficient of CEDU is negative and insignificantly related to ROA. It means that the firm's profitability goes downward if a person has the slot of the chief executive officer (CEO) and chairmanship as well. Our result is consistent with the previous result found by Liu (2019) in Nederland, which concludes that if chief executive officer is also working as chairman of board, it will affect the performance of the firm because one person cannot perform the responsibility of two. The observation of the coefficient of BRSIZ is negative and significantly related to ROA. It means that the firm's profitability goes downward and our result is consistent with the previous result found by Kalsie and Shrivastav (2016) in India argued that if Board size is large and every responsibility performed by the specific person, the result will be better as compared to the small size of the Board. The observation of the coefficient of BRCMT is positive and insignificantly related to ROA. It means that the firm's profitability goes upward, and our result is consistent with the previous result found by Mohd (2016) in Malaysia argued that if Board has relevant education have a positive effect on the performance. The observation of the coefficient of BREDU is positive and insignificantly related to ROA. It means that the firm's profitability goes upward, and our result is consistent with the previous result found by Mohd (2016) in Malaysia argued that if Board has relevant education have a positive effect on the performance. The observation of the coefficient of BRGDR is positive and significantly related to ROA. It means that the firm's profitability goes upward. Our result is consistent with the previous result found by Ramzi (2019) in France argued that if Board has female members, it has a positive effect on the performance of the firm. The observation of the coefficient of BREXP is positive and significantly related to ROA. It means that the firm's profitability goes upward when the Board has relevant experience, and our result is consistent with the previous result found by Musfiqur (2018) in Bangladesh argued that if Board has relevant experience, it hurts the performance of the firm. The observation of the coefficient of $\mathrm{BN}$ is positive and insignificantly related to ROA. It means that the firm's profitability goes upward when the 
Board has members of multiple nationality, and our result is consistent with the previous result found by Fernando (2020) in Spain argued that if board has female member, it has a positive effect on the performance of the firm. The observation of the coefficient of FRMSIZ is negative and significantly related to ROA. It means that the firm's profitability goes down when the firm has considerable assets. Our result is consistent with the previous result found by Oyelade (2019) in Nigeria argued that if the firm size is large, it results in will negatively affect the performance of the firm. The observation of the coefficient of BRCMP is positive and insignificantly related to ROA. It means that the firm's profitability goes upward when the Board has some suitable compensation or salaries, and our result is consistent with the previous result found by Fernandes (2005) in UAE argued that if Board has some compensation, it has a positive effect on the performance of the firm.

The value of $\mathrm{F}$ is 7.38 , which demonstrates that overall data model is good fit. The P-Value (F) of the data model is 0.000 which contrivance that the data model is significant. The $\mathrm{P}-\mathrm{Value}$ of Chow test is 0.000 which contrivance that Chow test is significant. The value of $\mathrm{P}-$ Value of Breusch-Pagan test is 0.000 which contrivance that Breusch-Pagan Test is significant. The value of $\mathrm{P}-\mathrm{Value}$ of Hausman test is 0.000 which contrivance that Hausman test is significant. The $\mathrm{P}$-Value of Wald test is also 0.000 which contrivance that Wald test is also significant.

Furthermore, in Table 6 the value of $\mathrm{R}$ squared is 0.523 , which means that the independent variable i.e., Chief Executive Duality, Board Size, Board Committees, Board Education, Board Gender, Board Experience, Board Nationality, Firm Size, and Board Compensation have $52 \%$ share in the increase of dependent variable i.e., Return on Asset (ROA).

\section{Dependent variable Tobin's $Q$}

Table 6 reports the results of model 3.1 of dependent variable TQ with all independent variables. We have allied fixed effect model as suggested by diagnostic test presented in Appendix A.

We observe the table we found that the coefficient of CEDU is negative and significantly related to TQ. It means that the firm trades in undervalue if a person has the slot of the chief executive officer (CEO) and chairmanship as well and our result is consistent with the previous result found by Satwinder (2017)

Table 6: Dependent variable: TQ.

\begin{tabular}{llllc}
\hline & Coefficient & Std. Error & t-ratio & p-value \\
\hline Const & 79.107 & 6.08668 & 12.9967 & $<0.00001$ \\
CEDU & -5.26689 & 2.52263 & -2.0879 & 0.03786 \\
BRSIZ & -3.33242 & 0.923332 & -3.6091 & 0.00037 \\
BRCMT & 1.32143 & 0.852171 & 1.5507 & 0.12229 \\
BREDU & 2.43539 & 1.5125 & 1.6102 & 0.10866 \\
BRGDR & 2.15102 & 0.994498 & 2.1629 & 0.03153 \\
BREXP & 0.0769655 & 0.0300626 & 2.5602 & 0.01107 \\
BN & 0.630075 & 0.750442 & 0.8396 & 0.40196 \\
FRMSIZ & -7.55526 & 0.55863 & -13.5246 & $<0.00001$ \\
BRCMP & $-3.79615 \mathrm{e}-05$ & 0.0013203 & -0.0288 & 0.97709 \\
R-squared & 0.564712 & & Adjusted R-squared & 0.499958 \\
F(36, 242) & 8.720922 & & P-value(F) & $* 3 *$ \\
P-value (CT) & 0.0000 & & P-value (BPT) & $3.18 \mathrm{e}-27$ \\
P-value (HT) & 0.0000 & P-value (WT) & 0.0000
\end{tabular}

Note: ${ }^{*}, * * * * *$ denotes significance level for $1 \%, 5 \%$ and $10 \%$, respectively.

Model 2: TQ $=\alpha+\beta 1 \times$ CEDUit $+\beta 2 \times$ BRSIZit $+\beta 3 \times$ BREDUit $+\beta 4 \times$ BREDUit $+\beta 5 \times$ BRGDRit $+\beta 6 \times$ BREXPit $+\beta 7 \times$ BRDIVit $+\beta 8 \times$ FRMSIZit $+\beta 9 \times$ BRINDPit $+\beta 10 \times$ BRCMPit $+€$

$\overline{T Q}$ is dependent variable and stand for Tobin's $Q . A$ is constant (intercept). B1 to B10 are regression coefficients. $€$ stands random error. The independent variables are CEDU stand for Chief Executive Duality. BRSIZ stand for Board Size. BREDU stand for Board Committees. BREDU stand for Board Education. BRGDR stand for Board Gender. BREXP stand for Board Experience. BN stand for Board Nationality. FRMSIZ stand for Firm Size and BRCMP stand for Board Compensation. CT, BPT, HT and WT are diagnostic tests and stand foe Chow test, Breusch-Pagan test, Hausman test and Wald test respectively and table of diagnostic tests are presented in appendix A.

June 2021 | Volume 40 | Issue 1 | Page 86 
in Pakistan argued that if Chief Executive Officer is also working as Chairman of Board, it will negatively affect the performance of the firm. The observation of the coefficient of BRSIZ is negative and significantly related to TQ. It means that the firm trades are undervalue when the size of a board member is extensive, and our result is consistent with the previous result found by Vaidya (2020) in BSE argued that if Board size is large it resultant on the firm performance is negative. The observation of the coefficient of BRCMT is positive and insignificantly related to TQ. It means that the firm trades in overvalue, and our result is consistent with the previous result found by Ramadan (2014) in the UK argued that if Board has multiple committees, it has a positive effect on the performance. The observation of the coefficient of BREDU is positive and insignificantly related to TQ. It means that the firm trades in overvalue when the Board has relevant education, and our result is consistent with the previous result found by Darmadi (2011) in Indonesia argued that if Board has relevant education have a positive effect on the performance. The observation of the coefficient of BRGDR is positive and significantly related to TQ. It means that the firm trades are in overvalue when the Board has female members, and our result is consistent with the previous result found by Tomislava (2016) in Croatian argued that if Board has female members, it has a positive effect on the performance of the firm. The observation of the coefficient of BREXP is positive and significantly related to TQ. It means that the firm trades is in overvalue when the Board has relevant experience, and our result is consistent with the previous result found by Fairchild (2005) in Spain argued that if Board has relevant experience, it has a positive effect on the performance of the firm. The observation of the coefficient of $\mathrm{BN}$ is positive and insignificantly related to TQ. It means that the firm trades in overvalue when the Board has members of multiple nationality and our result is consistent with the previous result found by Smith (2006) in Nigeria argued that if Board has foreign member, it has a positive effect on the performance of the firm. The observation of the coefficient of FRMSIZ is negative and significantly related to TQ.It means that the firm trades in undervalue when the firm has considerable assets, and our result is consistent with the previous result found by Robert (2005) in India argued that if Board has a large size, it harms the performance of the firm. The observation of the coefficient of BRCMP is negative and insignificantly related to TQ. It means that the firm trades in undervalue when the Board has some suitable compensation or salaries, and our result is consistent with the previous result found by Satwinder (2017) in British argued that if Board has some remuneration, it harms the performance of firm because due to the salary border.

The value of $\mathrm{F}$ is 8.72 demonstrate that overall data model is good settled. The P-Value (F) of the data model is 0.000 which contrivance that the data model is significant. The $\mathrm{P}$-value of Chow test is 0.000 which contrivance that Chow test is significant. The value of $\mathrm{P}$-value of Breusch-Pagan test is 0.000 which contrivance that Breusch-Pagan test is significant. The value of $\mathrm{P}$-value of Hausman test is 0.000 which contrivance that Hausman Test is significant. The $\mathrm{P}$-Value of Wald test is also 1.307 which contrivance that Wald test is not significant.

Furthermore, in Table 6 the value of $R$ squared is 0.564, which means that the independent variable i.e., Chief Executive Duality, Board Size, Board Committees, Board Education, Board Gender, Board Experience, Board Nationality, Firm Size, and Board Compensation have $56 \%$ share in the increase of dependent variable i.e., Tobine Q(TQ).

\section{Conclusions and Recommendations}

Corporate Governance indicators have a growing position for stakeholders worldwide, especially in developing countries and performing the role of pillar. Corporate governance is has been widely discussed in developing countries with microscopic studies.

In this study, the authors argued on the performance indicators Return on Asset and Tobin-Q with the association of Corporate Governance indicators Chief Executive Duality, Board Size, Board Committees, Board Education, Board Gender, Board Experience, Board Nationality, Firm Size, and Board Compensation. The coefficient of dependent variable Return on Asset (ROA) argued that Board Gender, Board Experience, Board Size and Firm Size have significant on the Return on Asset (ROA) which means that if there is any change in Board Gender, Board Experience, Board Size and Firm Size it is effecting the ROA. Furthermore, the $\mathrm{R}^{2}$ of Return on Asset results demonstrate a value 0.5234, which means that the independent variable have 52\% share on the benevolence of independent variables 
(ROA). The coefficient of dependent variable Tobin Q (TQ) with the independent variables of the study demonstrations that Chief Executive Duality, Board Gender, Board Size, Board Experience and Firm Size have significant impact ROA, which means that if there is any change in Chief Executive Duality, Board Gender, and Board Experience it will affect the ROA. Furthermore, the $\mathrm{R}^{2}$ of Tobin-Q results demonstrate a value 0.5647 , which means that the independent variables have $56 \%$ shares on the benevolence of independent variables.

Due to a time constraint and data limitations, the analysis was restricted to study only ten years data to construct index of performance with Corporate Governance Practices. However, the study can be extended to more than ten years data. Secondly, due to the data limitations, the analysis was restricted to only two governance variables in a panel setup. Constructing a governance index incorporating a larger set of governance parameters can further extend the study. Furthermore, response variable included Return on Equity, Return on Sale, and Return on investment can be incorporated in study.

The authors, theoretical implications contribute to the literature knowledge on two dimensions discussed in terms of Corporate Governance Practices with the associate with Firm Performance. The practical implication this the study contributing the awareness to Investor, shareholder, stockholders, Creditor, Manager, Customer, Society, Government, and employees of the associate between the Corporate Governance Practice with Firm Performance

\section{Novelty Statement}

This study is first of its kind to focus on non-financial firms (conducted combinedly on three sectors like cement, food and pharma) for the period of 10 years (2010 to 2019).

\section{Author's Contribution}

Allauthors contributed equally in this research.

\section{Conflict of interest}

The authors have declared no conflict of interest.

\section{References}

Abbas, A., H.A. Naqvi and H.H. Mirza. 2013. Impact of large ownership on firm performance: A case of non-financial listed companies of Pakistan. World Appl. Sci. J., 21(8): 1141-1152.

Abidin, Z.Z., N.M. Kamal and K. Jusoff. 2009. Board structure and corporate performance in Malaysia. Int. J. Econ. Finance, 1(1): 150-164. https://doi.org/10.5539/ijef.v1n1p150

Adkins, L.C., R.C. Hill, W.E. Griffiths and G.C. Lim. 2011. Using Stata for principles of econometrics ( $4^{\text {th }}$ ed.). New York, NY: Wiley.

Alabdullah and Ahmed. 2016. Corporate Governance: To What Extent it is important in the Arab Countries?: International Journal of Science and Research, 7(11): 1174-1175.

Akkermans, et al., 2007. Corporate Governance in the Netherlands: An Overview of the Application of the Tabaksblat Code in 2004: Journal compilation, 15(6): 1106-1118

Armstrong, J.B., Schindler, D.E. 2013. Going with the Flow: Spatial Distributions of Juvenile Coho Salmon Track an Annually Shifting Mosaic of Water Temperature. Ecosystems 16, 1429-1441

Baumol, W. 1959. The Theory of the Revenue Maximizing Firm: Journal of Service Science and Management 1(2): 124-141

Bohren, O. and R.O. Strom. 2010. Governance and politics: Regulating independence and diversity in the board room. J. Bus. Finance Account., 37: 1281-1308. https://doi.org/10.1111/ j.1468-5957.2010.02222.x

Coles, J., N. Daniel and L. Naveen. 2008. Boards: Does one size fit all? J. Financ. Econ., 87(2): 329-356. https://doi.org/10.1016/j. jineco.2006.08.008

Conyon, M.J. and S.I. Peck. 1998. Board size and corporateperformance:EvidencefromEuropean countries. Eur.J. Finance, 4(3): 291-304. https:// doi.org/10.1080/135184798337317

Costa, M.D., 2015. Impact of CEO duality and board independence on FTSE small cap and fledging company performance. World Rev. Bus. Res., 5(1): 1-19.

Darmadi, S. 2011. Board Diversity and Firm Performance: The Indonesian Evidence (December 17, 2010). Corporate Ownership and Control Journal, Vol. 8, 2011 
Drobetz et al., 2004. Corporate Governance and Expected Stock Returns: Evidence from Germany. European Financial Management. 10(2): 267-293

Fama, 1980. Agency Problems and the Theory of the Firm; Journal of Political Economy. 88(2): 288-307.

Fama and Jensen, 1983. Separation of Ownership and Control; Journal of Law and Economics, Vol. 26,

Financial Reporting Council, 2016. The UK Corporate Governance Code. Retrieved from https://www.frc.org.uk/ getattachment/ ca7e94c4-b9a9-49e2-a824-ad76a322873c/ UK-Corporate-Governance-Code-April-2016. pdf

Francis, B., I. Hasan and L. Song. 2012. Are firmand country-specific governance substitutes? Evidence from financial contracts in emerging markets. J.Financ. Res., 35(3): 343-374.https:// doi.org/10.1111/j.1475-6803.2012.01320.x

Ferreira, L., Carneiro, R., Paes, S., Schallig, G., 2007. Comparison of serological assays for the diagnosis of canine visceral leishmaniasis in animals presenting different clinical manifestations. Veterinary Parasitology 146: 235-241

Hasan, I., and L. Song. 2013. Public disclosure and bank loan contracting: Evidence from emerging markets. Asian Review of Accounting (Forthcoming). https://doi.org/10.1108/ARA10-2013-0069

Hewa-Wellalage and Locke 2011. Ownership Structure and Firm Financial Performance: Evidence from Panel Data in Sri Lanka; ournal of Business Systems Governance \& Ethics 7(1): $52-65$.

Jensen, M.C., 1993. The modem industrial revolution, exit, and the failure of internal control systems. J. Finance, 48(3): 831-880. https://doi.org/10.1111/j.1540-6261.1993. tb04022.x

Jensen, M.C., and H. Meckling. 1976. Theory and the firm: Managerial behavior, agency costs and ownership structure. J. Financ. Econ., 3(4): 305-360. https://doi.org/10.1016/0304405X(76)90026-X

Kalsie and Shrivastav, 2016. Analysis of Board Size and Firm Performance: Evidence from NSE Companies Using Panel Data Approach; Indian Journal of Corporate Governance
9(2):148-172.

Lin, Z.P., H. Yang and S.L. Sun. 2009. How do networks and learning drive $\mathrm{M}$ and As? An institutional comparison between China and the United States. Strateg. Manage. J., 30(10): 1113-1132. https://doi.org/10.1002/smj.777

Liu, 2019. CEO Duality and Firm Performance Under Endogeneity; The university of Chicago; (July 12, 2019)

Ma, S., and G. Tian. 2014. Board composition, board activity and ownership concentration, the impact on firm performance. SSRN Electron. J.,. https://doi.org/10.2139/ssrn.2496168

Mesut B. , Aksu N. B. , Ozsoy Y. 2013. Design of Sustained Release Tablet Formulations of Alfuzosin $\mathrm{HCl}$ by means of Neuro-Fuzzy Logic: Latin American Journal Of Pharmacy; 32: 1288-1297

Mihaela 2016. The relation between economic growth and foreign direct; Proceedings of Rijeka School of Economics 34(1) 187-213

Muttakin, M.B., A. Khan and N. Subramaniam. 2012. Board structure and firm performance: Evidence from an emerging economy. Acad. Taiwan Bus. Manage. Rev., 8(2): 97-108.

Nahar, A.S., 2006. Directors' remuneration, firm's performance and corporate governance in Malaysia among distressed companies. Corp. Governance Int. J. Bus. Soc., 6(2): 162-174. https://doi.org/10.1108/14720700610655169

Noor, M., and F. Fadzil. 2013. Board characteristics and performance from perspective of Governance Code in Malaysia. World Rev. Bus. Res., 3(3): 191-206.

OECD, 2004. Principles of corporate governance. Retrieved from

Pearce, II, J.A., and S.A. Zahra. 1992. Board composition from a strategic contingency perspective. J. Manage. Stud., 29(4): 411-438. https://doi.org/10.1111/j.1467-6486.1992. tb00672.x

Perry, T., 2000. Incentive compensation for outside directors and $\mathrm{CEO}$ turnover. Paper presented at Tuck-JFE Contemporary Corporate Governance Conference. https:// doi.org/10.2139/ssrn.236033

Rahman, M.M., and N. Khatun. 2017. Quality of corporate governance: A review from the literature. J. Asian Finance, Econ. Bus., 4(1): 59-66. https://doi.org/10.13106/jafeb.2017. vol4.no1.59 
Reese,W.A.,Jr.,andM.S.Weisbach.2002.Protection of minority shareholder interests, cross-listings in the United States, and subsequent equity offerings. J. Financ. Econ., 66: 65-104. https:// doi.org/10.1016/S0304-405X(02)00151-4

Rowley, T.J., A.V. Shipilov and H.R. Greve. 2017. Board reform versus profits: The impact of ratings on the adoption of governance practices. Strateg. Manage. J., 38(4): 815-833. https://doi. org/10.1002/smj. 2545

Ramzi Ben Slama, Aymen Ajina \& Faten Lakhal (2019) Board gender diversity and firm financial performance in France: Empirical evidence using quantile difference-in-differences and dose-response models, Cogent Economics \& Finance, 7:1, 1626526

Salacuse, J.W., 2002. Corporate governance in the UNECE region. Retrieved from United Nations Economic Commission for Europe website: https://www.unece.org/fileadmin/ DAM/oes/disc_papers/ECE_DP_2002-2.pdf

Sklair, L., 2001. The transnational capitalist class. Oxford, England: Blackwell.

Smith, A., 2006. An inquiry into the nature and causes of the wealth of nations. Oxford, England: The Clarendon Press. https://doi. org/10.1093/oseo/instance.00043218

Sobhan, A., and S. Bose. 2019. Institutional characteristics and outcomes of corporate governance in Bangladesh: Research challenges. In: I. Tsalavoutas and P. Weetman (Eds.) The Routledge Companion to Accounting in Emerging Economies. pp. 1-26. https://doi. org/10.4324/9781351128506-16

Sunstein \& Vermeule , 2009. Conspiracy Theories: Causes and Cures; The Journal of Political Philosophy, 17(2): 202-227

Terjesen, S., E.B. Couto and P.M. Francisco. 2016. Does the presence of independent and female directors impact firm performance? A multicountry study of board diversity. J. Manage.
Governance, 20(3): 447-483. https://doi. org/10.1007/s10997-014-9307-8

Tregear,A.,andM.Ness.2005.Discriminantanalysis of consumer interest in buying locally produced foods. J. Market. Manage., 21(1-2): 19-35. https://doi.org/10.1362/0267257053166811

Topak 2011. The Effect of Board Size on Firm Performance: Evidence from Turkey: Middle Eastern Finance and Economics; 14: 121-126

Tulung,J.E., and D. Ramdani. 2018. Independence, size and performance of the board: An emerging market research. Corp. Owners. Contr., 15(2-1): 201-208. https://doi.org/10.22495/ cocv15i2c1p6

Vaidya, 2019. Board Size and Firm Performance: A Study on BSE 100 Companies; Journal of Management 6(3), 117-123

Vafeas, 2000. Board structure and the in formativeness of earnings; Journal of Accounting and Public Policy, (19)2, 139-160.

Weir, C., D. Laing and P.J. McKnight. 2002. Internal and external governance mechanisms: Their impact on the performance of large UK public companies. J. Bus. Finance Account., 29(6): 579-612. https://doi.org/10.1111/14685957.00444

Whiting P, Al M, Westwood M, Ramos I, Ryder S, Armstrong $\mathrm{N}$, et al. Viscoelastic point-of-care testing to assist with the diagnosis, management and monitoring of haemostasis: a systematic review and cost-effectiveness analysis. Health Technol Assess 2015;19(58)

Yapa A.D.,2016. Impact of capital structure on firm performance: Evidence from manufacturing sector SMEs in UK. SSRN Electron. J.,

Yermack, 1996. Higher market valuation of companies with a small board of directors: Journal of Financial Economics, 40(2): 185-211

Yapa A.D., 2016. Impact of capital structure on firm performance: Evidence from manufacturing sector SMEs in UK. SSRN Electron. J. 